\title{
ADDITIONAL RECORDS FOR SOME RARE OR UNCOMMON NATIVE ORCHIDS IN SASKATCHEWAN
}

VERNON L. HARMS, Fraser Herbarium, Department of Plant Ecology, Universi of Saskatchewan, Saskatoon

During the last several years, field work, especially in northern Saskatchewan, by the author, associates and students has resulted in additional locality records and a better distributional knowledge of various rare native orchid species in the province. Other earlier collections have often been filed in herbaria but not reported in the literature. The intent of this article is to share the present distributional information regarding these orchids with other botanists and naturalists who have an interest in the Saskatchewan flora. Included for each species are previous locality reports in the literature, recent records, and all additional herbarium specimens seen by the author (SASK = Fraser Herbarium, University of Saskatchewan; USAS = Herbarium, University of Regina, and the Saskatchewan Natural History Museum). The known distributions of these orchids in Saskatchewan are then mapped to better portray their ranges in the province.

The STRIPED CORAL-ROOT, Corallorhiza striata Lindl., was previously reported in Saskatchewan by Breitung from Wallwort, Moose Mountain, Kelliher, Langbank and the Cypress Hills. ${ }^{2}$ In addition, herbarium specimens have been seen from Theodore, 26 miles NW of Yorkton (George Brown, SASK) and from Boomerang Lake, 3 miles NE of Runnymede, 3-4 miles $S$ of Duck Mountain Prov. Park (T 29 N, R 30 W 1st $M$ ), (G. F. Ledingham and E.B. Peterson 4748, USAS). Newly reported locality records for this rare orchid species include the following: about miles SW of Dundurn Military Cam (Sec. 32, T 32 N, R 5 W 3rd M), aspe grove ravine in dune sand area, Jur 1971, B. Felski \& B. Pegg (SASK); Pih Lake, 18 miles S-SW of Saskatoon ( $T$ $N$, R 6 W 3rd M), near nature trail S lake in moist rich woodland, June 1 1975, K. Meeres (SASK); 16 miles N-N of St. Walburg near Highway 26 (SE Sec. 25, T 55 N, R 22 W 3rd M), moi semi-open aspen woods, May 21, 197 1. Haraldson (SASK). The prese records extend the known Sask chewan range of this species no thwestward to the Saskatoon area ar the southern boreal forest fringe at 5 Walburg (see map 1). The plants, whic are characteristic of rich aspen wood are reportedly very rare at each know site in the province.

The LARGE ROUND-LEAVED BC ORCHID, Habenaria orbiculata (Purs Torr., was previously reported Saskatchewan from Torch River ( $N$ Nipawin) and Amisk Lake by Breitu and from Weber Bay of Lac la Plon by Harms and Hudson. ${ }^{2}$ Herbariu specimens have also been seen from Ronge (J. S. Maini \& M. Swan 61 SASK), Big Sandy Lake on the Hans Lake Road (C. W. Argus 4237, SASt the Candle Lake area (J. M. A. Sw 230, H. C. Anderson 1256, SASK; $R$. Russell 15-9-1959, USAS) and Pinkn Lake, 35 miles NE of Candle Lake (J. A. Swan 64-45, SASK). Newly report locality records for this species in $t$ province are the following: McLenn Lake, Mile 83 of Highway 102, NE of Ronge $\left(55^{\circ} 55^{\prime} \mathrm{N}, 104^{\circ} 18^{\prime} \mathrm{W}\right)$, mo 
bracteata (Muhl.) Gray, was reported by Breitung to be "common in meadows and borders of sandy woods". ${ }^{2}$ However, in our experience the species appears quite sporadic in occurrence, and is certainly uncommon, if not actually rare, in Saskatchewan. In the Fraser Herbarium, there are older specimens from the Cypress Hills, Prince Albert, MacDowall, McKague, Candle Lake, Strawberry Lakes S of Indian Head, Willow Bunch and Warmley. Additional new records include the following: Greenwater Lake ( $T 41 \mathrm{~N}, \mathrm{R}$ $11 \mathrm{~W}$ 2nd $M$ ), aspen woods, June 19, 1973, V. L. Harms 19709 (SASK); Shell Lake, Valley of Shell Brook (NE $1 / 4 \mathrm{Sec}$. 27, T $50 \mathrm{~N}, \mathrm{R} 8 \mathrm{~W} 3 \mathrm{rd} \mathrm{M}$ ), aspen woods, May 30, 1976, /. H. Hudson 3122 (SASK); Meadow Lake Prov. Park, between Lac des Isles and Mistohay Lake (Sec. 13, T 63 N, R 22 W 3rd M), aspen forest, July 1, 1976, V. L. Harms 23461 (SASK); Dundurn area (T $33 \mathrm{~N}, \mathrm{R}$ $4 \mathrm{~W}$ 3rd M), sandy shady poplar willow grove July 27, 1972, E. W. Sullivan 422 (USAS). The plants appear to be locally rare at most, if not all, of the above listed sites where it is known in the province (see map 3).

The VENUS'SLIPPER ORCHID, Calypso bulbosa (L.) Oakes, was previously reported in Saskatchewan by Raup from Lake Athabasca, by Breitung from Bjorkdale, Torch River ( $N$ of Nipawin) and the Cypress Hills, and by Jeglum from Candle Lake. ${ }^{5} 24$ Additional Saskatchewan records for this species are the following: $N$ of

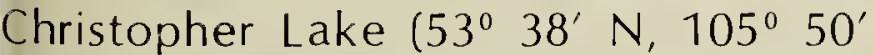
W), white spruce -- jack pine forest, May 22, 1972, T. F. Cameron 301 (SASK); Mile 4 of Highway $102, \mathrm{~N}$ of La Ronge $\left(\begin{array}{lllll}55^{\circ} & 10^{\prime} & \mathrm{N}, 105^{\circ} & 20^{\prime} & \mathrm{W}\end{array}\right)$, mixedwood forest, May 30, 1961, J. S. Maini 403 (SASK) June 4, 1972, I. Ternier \& S. Lamont 40 (SASK); Mile 8 of Highway 102, $\mathrm{N}$ of La Ronge $\left(55^{\circ} 12^{\prime}\right.$ $\mathrm{N}, 105^{\circ} 17^{\prime} \mathrm{W}$ ), jack pine forest, June 14, 1960, J. S. Maini 19 (SASK); E shore of Pita Lake on Churchill River $\left(55^{\circ} 34^{\prime}\right.$

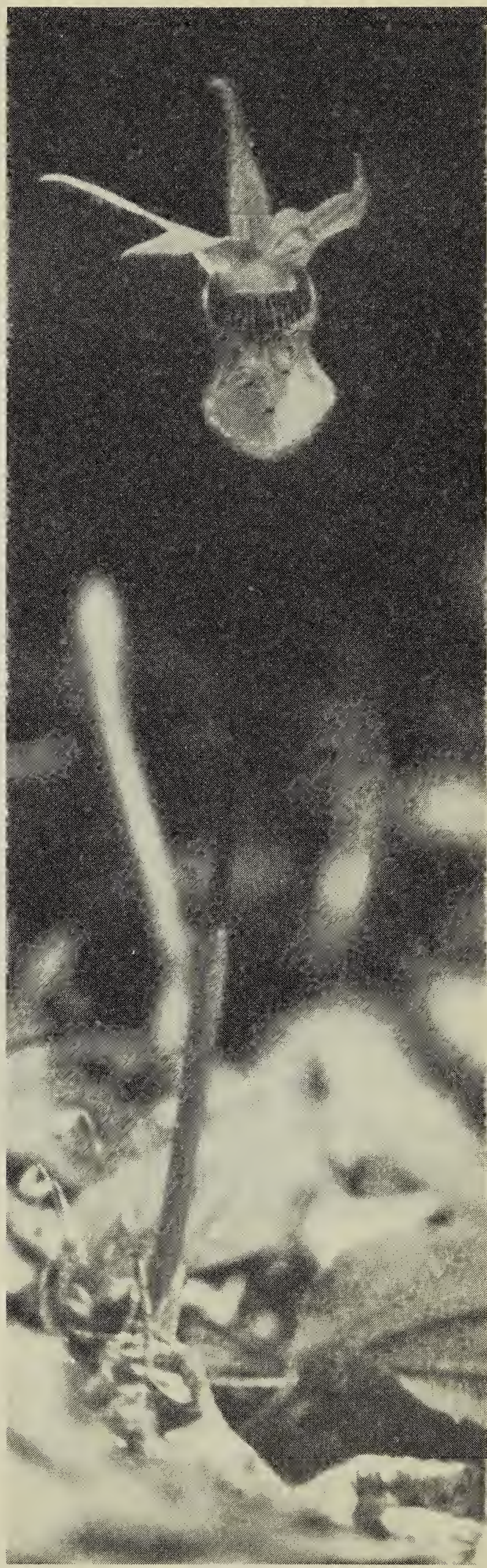

Venus'-slipper orchid

Bob Codwin 


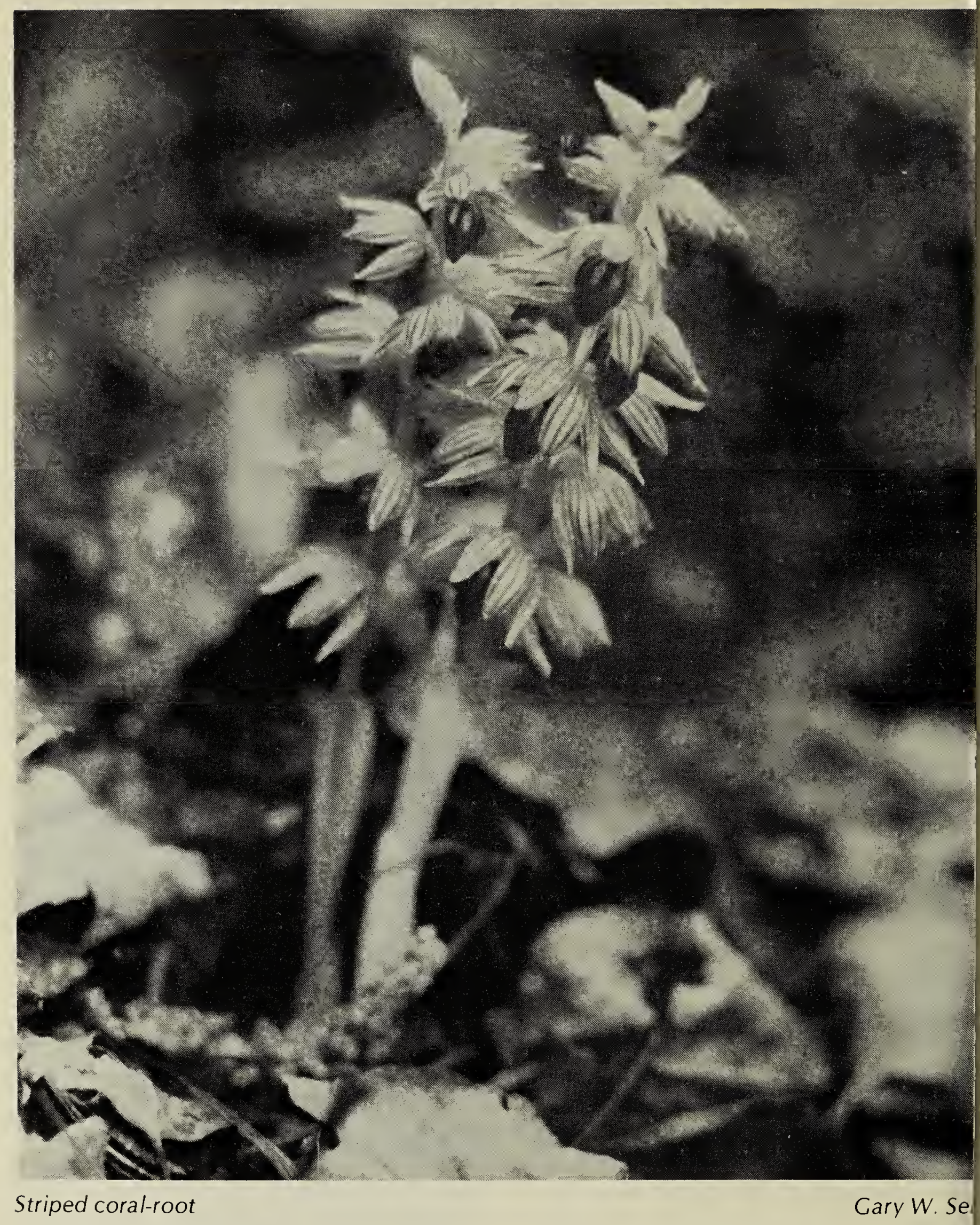

aspen - white birch - black spruce mixedwood forest, July 26, 1972, J. Ternier \& S. Lamont 1077 (SASK); Prince Albert Natl. Park, at Kingsmere River, NW of Waskesiu Lake $\left(54^{\circ} 02^{\prime} \mathrm{N}, 106^{\circ}\right.$ $25^{\prime} \mathrm{W}$ ), tall mixedwood forest, June 10 , 1971, T. F. Cameron 312 (SASK). The present records better fill in the species range in the southern boreal forest region of Saskatchewa Although this sporadically occurrir orchid appears not to be as rare in $t h$ province as once thought, it is hard frequent, and reportedly is locally ra at most known sites (see map 2).

The LONG-BRACTED BOG O CHID, Habenaria viridis (L.) R. Br. vé 


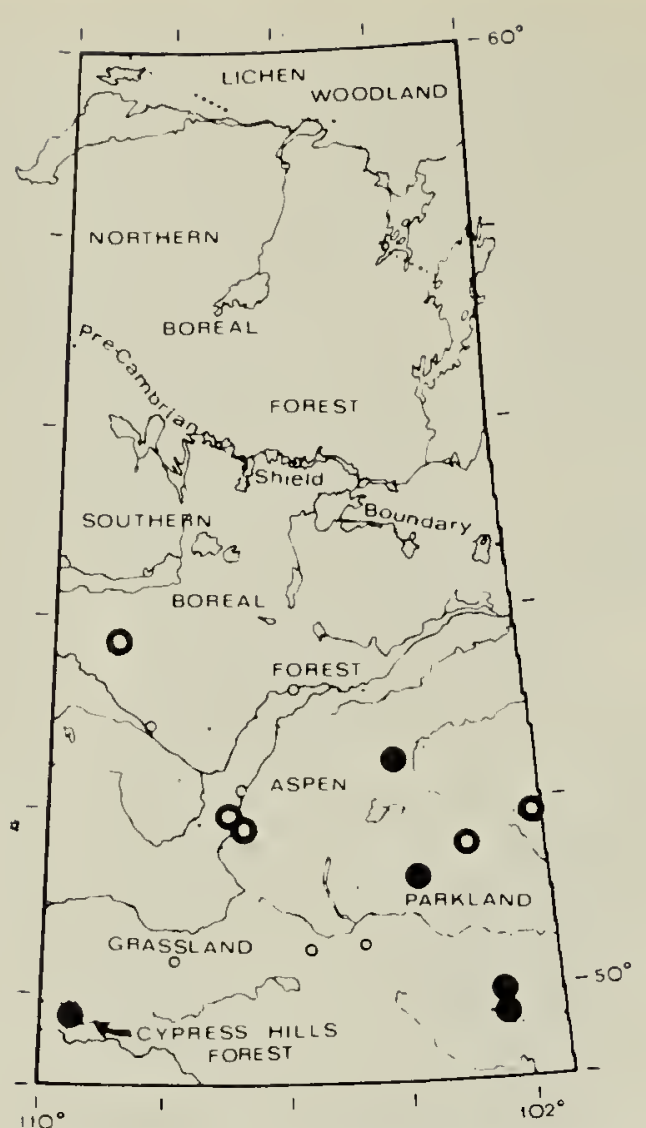

\section{STRIPED CORAL-ROOT (CORALLORHIZA STRIATA)}

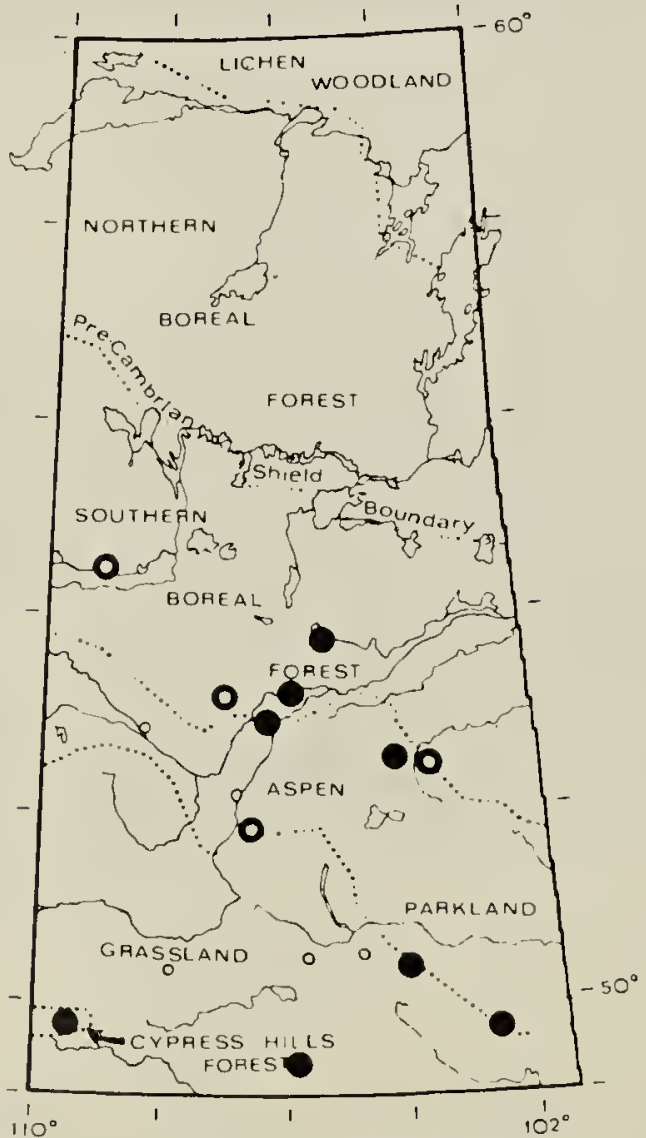

3. LONG-BRACTED BOG ORCHID (HABENARIA VIRIDIS

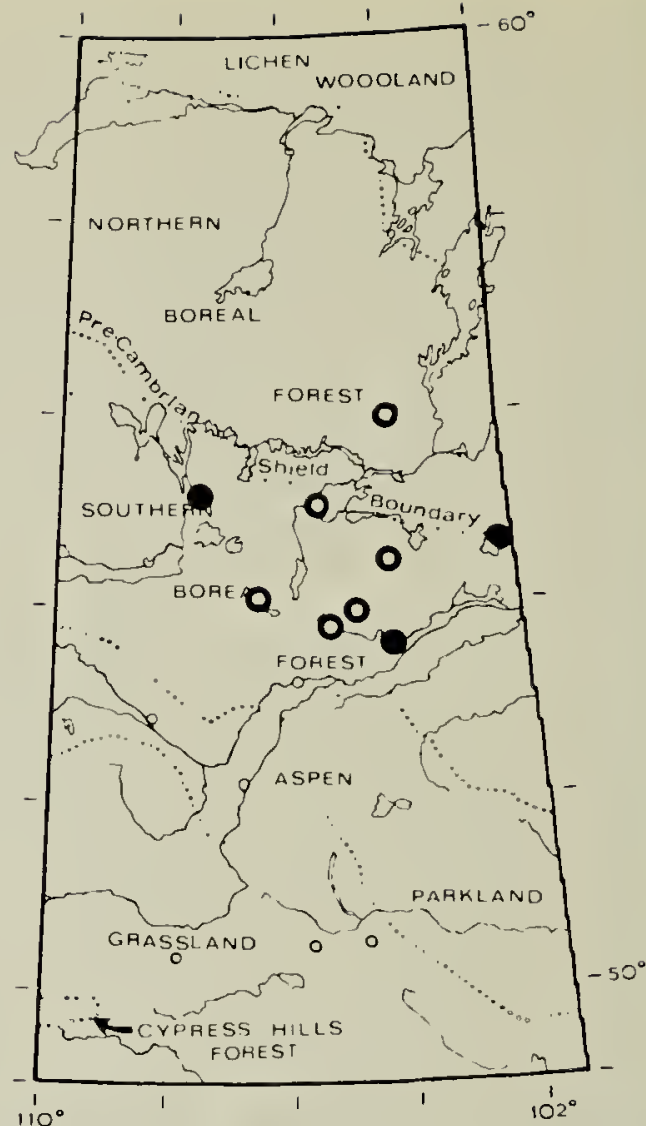

2. LARGE ROUND-LEAVED BOG ORCHID

(HABENARIA ORBICULATA)

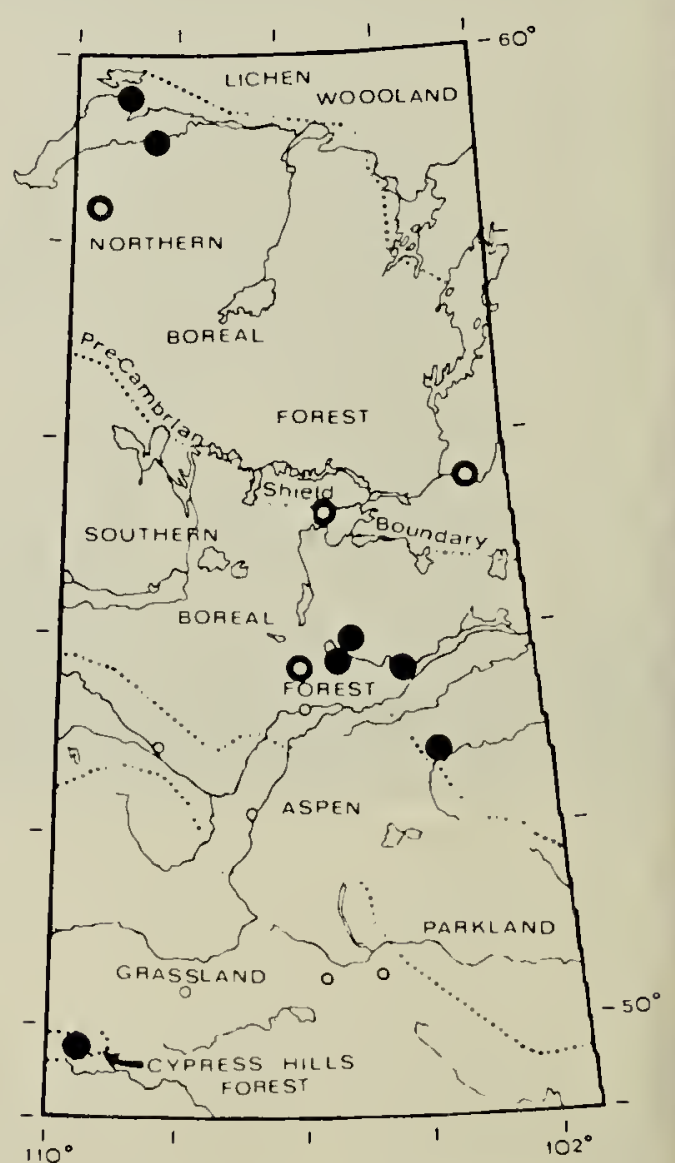

4. VENUS'-SLIPPER (CALYPSO BULBOSA)

Maps 1-4: The known Saskatchewan distribution of some rare or uncommon orchid specit (closed dots represent previous locality reports in the literature; open circles represent eith new or previously unreported herbarium records). 


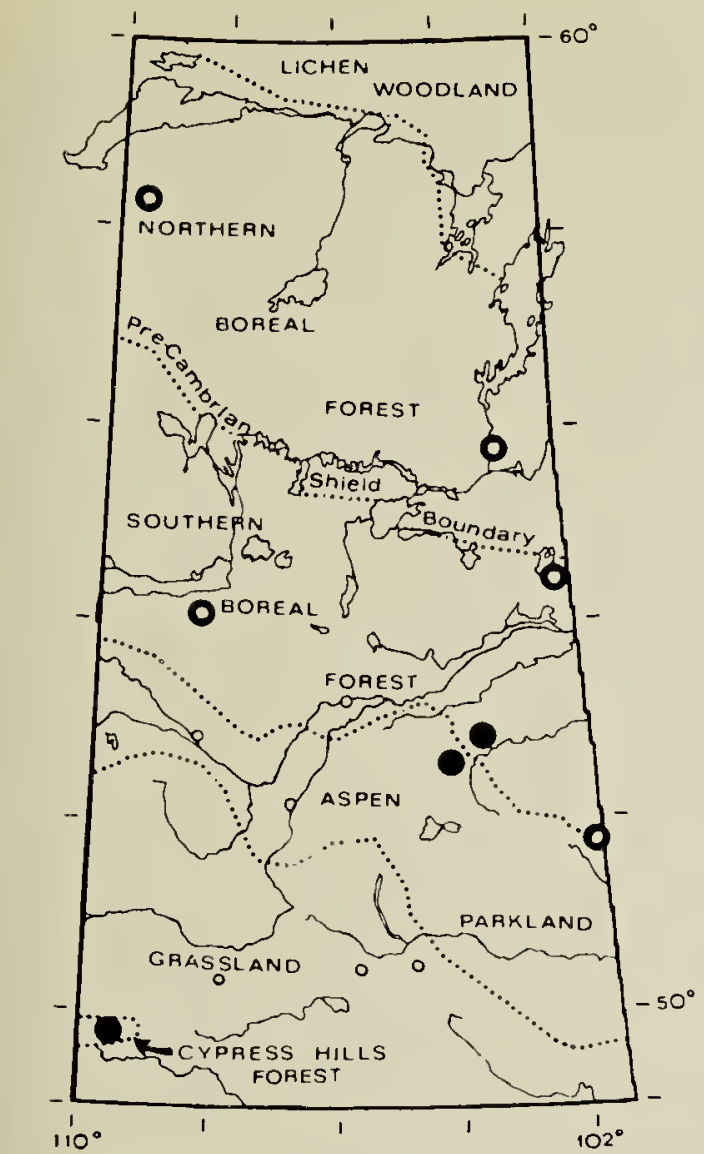

5. HEART-LEAVED TWAYBLADE (LISTERA CORDATA)

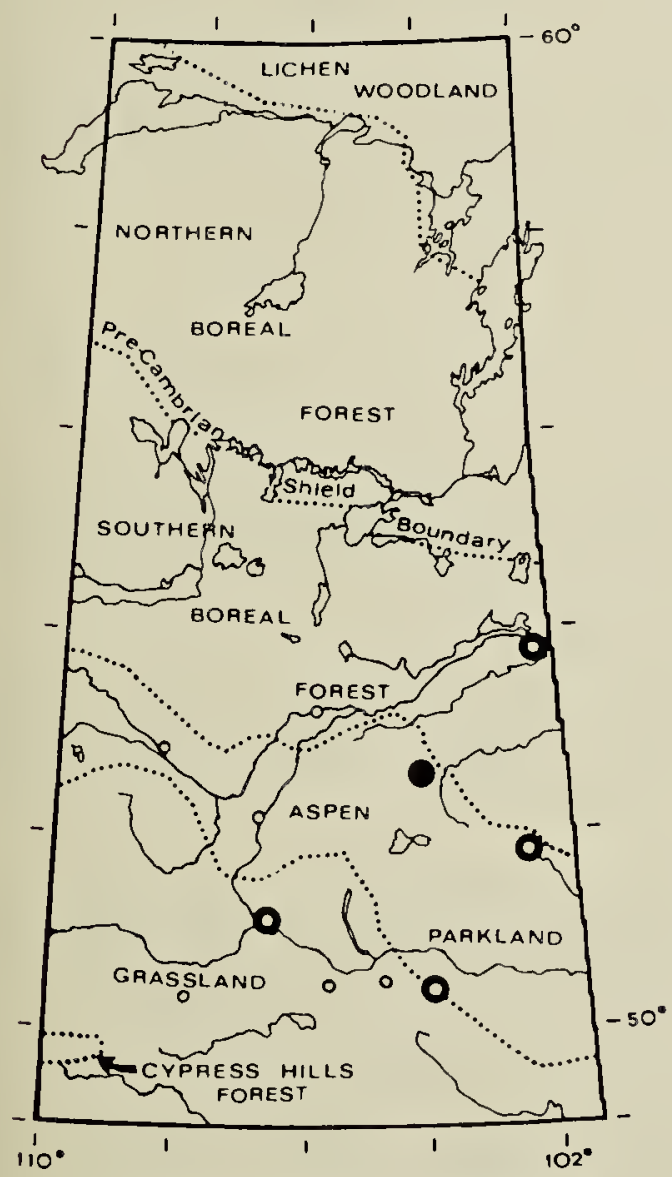

7. BOG TWAYBLADE (LIPARIS LOESELII)

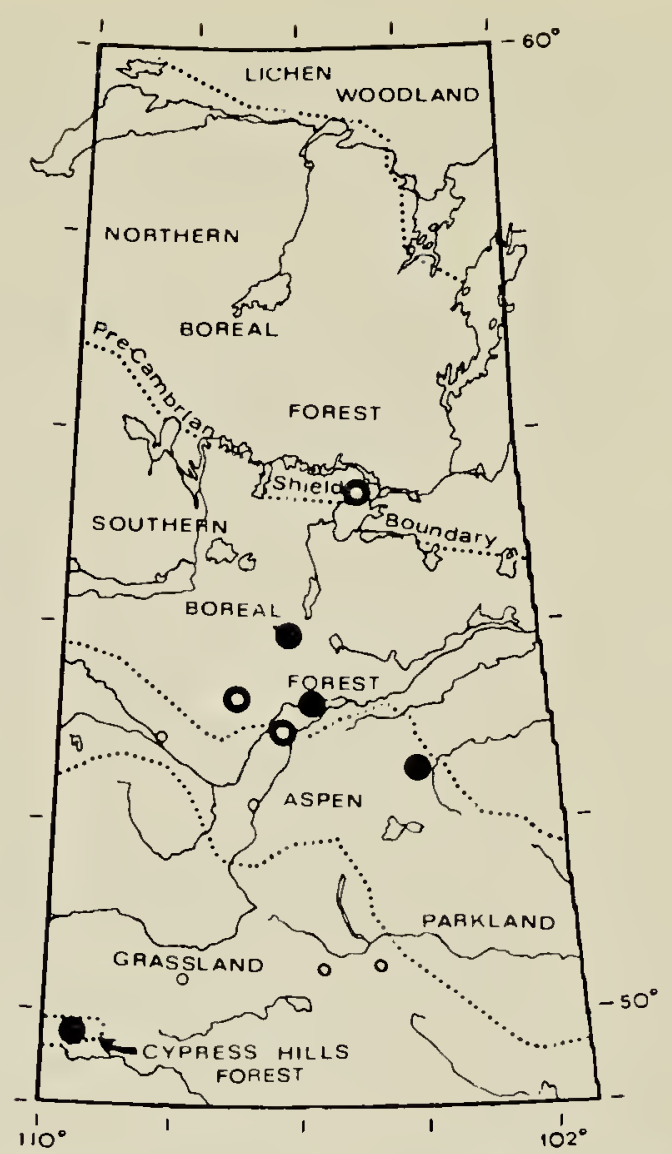

6. NORTHERN TWAYBLADE (LISTERA BOREALIS)

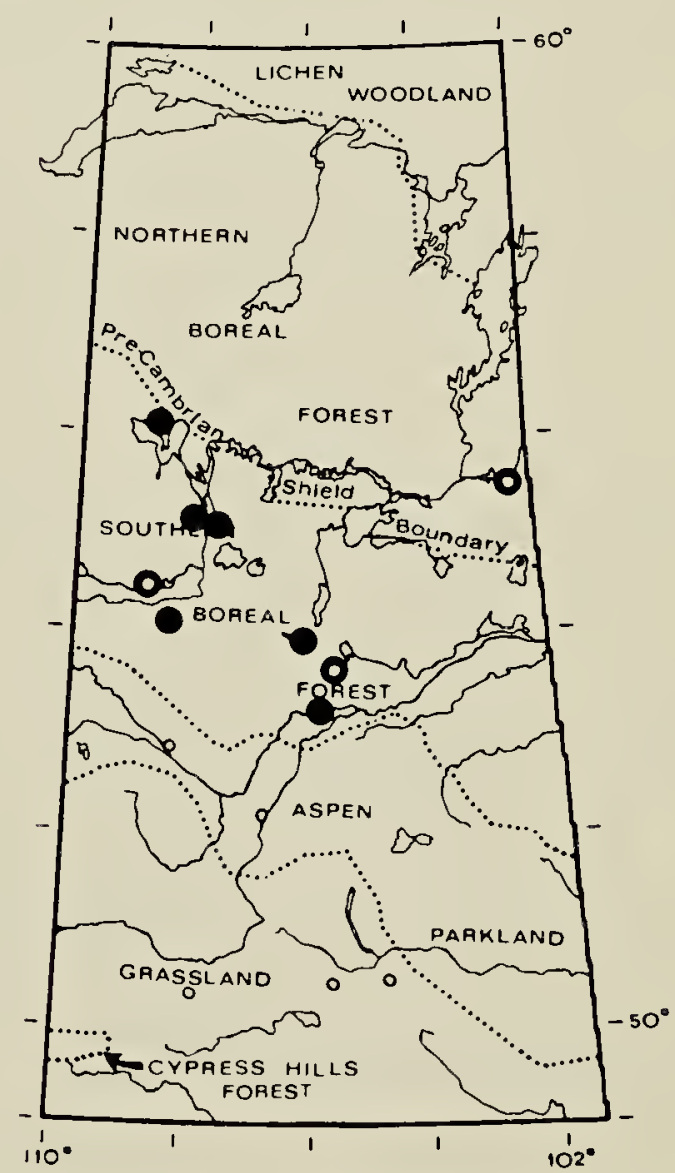

8. SLENDER LADIES'-TRESSES (SPIRANTHES GRACILIS)

Maps 5-8: The known Saskatchewan distribution of some rare or uncommon orchid species closed dots represent previous locality reports in the literature; open circles represent either ew or previously unreported herbarium records). 
Cypress Hills, McKague, Prince Albert and Waskesiu Lake. ${ }^{2}$ Additional locality records include the following: Lynx Lake, Mile 30 of Highway 102, N of La Ronge $\left(55^{\circ} 27^{\prime} \mathrm{N}, 1^{\circ} 05^{\circ} 00^{\prime} \mathrm{W}\right)$, willow marsh June 21, 1972, J. Ternier \& S. Lamont 409 (SASK); Shell Lake, valley of Shell Brook (NE 1/4 Sec. 27, T $50 \mathrm{~N}, \mathrm{R} 8 \mathrm{~W}$ 3rd $M$ ) white spruce woods, May 30, 1976, J. H. Hudson 3120 (SASK); MacDowall area (NW 1/4 Sec. 21, T $45 \mathrm{~N}, \mathrm{R} 1 \mathrm{~W}$ 3rd $M$ ), semiboggy spruce woods, July 8,1973, J. $H$. Hudson 2862 (SASK). These records help to fill in and also extend the known Saskatchewan range of this rare orchid species about 100 miles northward to Lynx Lake. In Saskatchewan, it seemingly represents a species which is characteristic of moist spruce woods and treed bogs in the southern boreal forest region and fringes, and also in the Cypress Hills (see map 6).

The BOG TWAY-BLADE, Liparis loeselii (L.) Richard, was reported in Saskatchewan by Breitung only from the Dahlton-McKague area. ${ }^{2}$ Additional records include the following: Cumberland House vicinity, Egg Lake, $\mathrm{S}$ of Saskatchewan River $\left(53^{\circ} 53^{\prime} \mathrm{N}\right.$, $102^{\circ} 20^{\prime} \mathrm{W}$ ), floating marsh Island, June 17, 1967, C. W. Argus 3995 (SASK); Dry Lake, Strawberry Lakes area, 12 miles $S$ of Indian Head (T 16 N, R 13 W 2nd M), wet open seepage shores and lake bed, June 21, 1966, G. L. Jones 556, July 27, 1966, C. F. Ledingham 4765 (SASK, USAS); Tadmore (SW $1 / 4$ Sec. 23, T 33 $N, R 4 \mathrm{~W} 2$ nd $M$ ), wet open marl-bog, July 11, 1974, J. H. Hudson 2968 (SASK); Elbow area, Douglas Prov. Park (T $24 \mathrm{~N}, \mathrm{R} 4 \mathrm{~W}$ 3rd M), wet boggy area, June, 1977, S. M. Lamont (to be deposited in USAS).

The SLENDER LADIES'-TRESSES ORCHID, Spiranthes gracilis (Bigel) Beck, has, been reported previously in Saskatchewan by Breitung from Prince Albert, Waskesiu Lake and Meadow Lake, and by Harms and Hudson from the Beauval-Lac la Plonge area, Little
Amyot Lake and Taylor Lake $\mathrm{N}$ Buffalo Narrows. ${ }^{2}{ }^{3}$ Newly reporte locality records in the province clude the following: $S$ end Sokatisewin Lake on the Churchi River $\left(\begin{array}{llll}55^{\circ} & 28^{\prime} \mathrm{N}, 102^{\circ} 25^{\prime} \mathrm{W}\end{array}\right)$, roo outcrops in jack pine forest, June 2 1974, I. \& . Heilman 1812B (SASK); 1 miles NW of Paddockwood, SW Candle Lake (Sec. 20, T 54 N, R 24 2nd $M$ ), open young aspen fores August 19, 1971, H. G. Anderson 142 (SASK); Meadow Lake Prov. Park, side of First Mustus lake $\left(54^{\circ} 25^{\prime}\right.$ $108^{\circ} 50^{\prime} \mathrm{W}$ ), (Sec. 4, T $63 \mathrm{~N}, \mathrm{R} 19 \mathrm{~W} 3 \mathrm{I}$ $M)$, open cleared moist depression July 24, 1974, V. L. Harms 20675 (SASK This eastern North American speci has been considered a rare species Saskatchewan, at the western limit its range here. Surprisingly, the prese Sokatisewin Lake record is the fir from eastern Saskatchewan or from c the Pre-Cambrian Shield in th province. The plants appear to $k$ locally rare at all known sites in th province except in the upper Church River area (Beauval to Buffa Narrows) (see map 8).

${ }^{1}$ BOIVIN, B. 1967. Enumeration des Plant du Canada, V-Monopsides (I ère partie Naturaliste Canadien 94: 131-157.

${ }^{2}$ BREITUNG, A. J. 1957. Annotat catalogue of the vascular flora Saskatchewan. The American Midla Naturalist 58: 1-72.

${ }^{3}$ HARMS, V. L. and J. H. HUDSON. 197 Some new and noteworthy vascul records from northwestern Sask. chewan. Rhodora 76: 39-44.

${ }^{4}$ JEGLUM, J. K. 1972. Boreal forest wetlan near Candle Lake, Central Sask. chewan. I. Vegetation. The Musk-Ox, N 11: 41-58.

${ }^{5}$ RAUP, H. M. 1936. Phytogeographic studies in the Athabasca-Creat Sla Lake region. I. Catalogue of the vascul plants. Journ. Arnold Arboretaun 17: 1$\}$ 315. 